\title{
Fluid Flow Characterization of Single-Strand Tundish with Flow Modifiers through Physical Water Model (PWM) and CFD Simulation
}

\author{
Jaywant Namdev Yadav ${ }^{1, *(\mathbb{D})}$, Netra Pal Singh 1 (1) \\ 1 Department of Mechanical Engineering, Oriental University, Indore 453555, MP-India \\ * Correspondence:jny.hydro@gmail.com;
}

Received: 25.02.2021; Revised: 2.04.2021; Accepted: 4.04.2021; Published: 19.04.2021

\begin{abstract}
The flow behavior in the continuous casting tundish dominates the quality and cleanliness of steel production. In this research, the single strand tundish's fluid flow behavior with different flow modifiers is investigated through numerical and experimental simulation. The numerical; simulation is performed in ANSYS FLUENT 19.2 (commercial package) and experimental through physical water model technique. The flow behaviors of bare tundish and tundish with three different flow modifiers are investigated. The three different flow modifiers deployed are the dam, baffle, and turbulence inhibiter (TI). Fluid flow performance is examined through residence time distribution (RTD) curves, which are derived from the measurement of the tracer concentration at the outlet. Good agreement between the CFD simulation and physical water model experiments is discovered. The results show there is an improvement in residence time and fluid flow (also improved inclusion removal) after the deployment of flow modifiers. There is a $20 \%$ improvement in peak and minimum residence time of RTD curves due to flow modifiers application. It is also discovered that the tundish configuration in this research, the tundish with turbulence inhibiter, provides optimal flow characteristics and eventually intended to promote a better level of inclusion removal.
\end{abstract}

Keywords: Tundish; RTD; fluid flow; PWM; simulation.

(C) 2021 by the authors. This article is an open-access article distributed under the terms and conditions of the Creative Commons Attribution (CC BY) license (https://creativecommons.org/licenses/by/4.0/).

\section{Introduction}

In the continuous casting process, the tundish provides a continuous flow of molten metal and acts as a secondary refining device. The refinement of molten metal in tundish is carried through floatation on non-metallic inclusions at the upper surface during residence. These floated inclusions are removed over from the surface. The tundish fluid flow plays an essential role in controlling the inclusion removal and residence time calculation. For achieving the tundish's optimum flow characteristics, the flow modifiers such as the dam, weir, baffle, turbulence inhibiter, impact pad, etc., are deployed [1-2]. In this research, the flow characteristics of the tundish with different flow modifiers are investigated. The investigation was performed through numerical simulation and water model methods. The authors have performed fluid flow analysis for different tundish configurations through the water model method and numerical simulation by utilizing ANSYS FLUENT 6.0. They deployed a k- $\varepsilon$ twoequation model of turbulence and RTD curves for analyzing the fluid flow behavior. They utilized tundish configurations as bare tundish and tundish with weir and dam. The optimum configuration for removing non-metallic inclusions was the tundish with weir and dam configuration [1-6]. The inlet cooling rate of the molten from ladle to tundish is analyzed 
through numerical simulation, and the flexible thin slab casting (FTSC) tundish is utilized. It was concluded that there was unstable when the stream temperature drops and stable when the temperature is heightened. This also presents that the inlet cooling rate affects the inclusion removal and the fluid flow in the tundish [3-10]. Numerical simulation on tundish consisting of some flow modifiers, they focused on the small addition of KCI solution to water effect on tundish. The carried out the density-coupled mixed composition fluid model methods like LVEL, Chen-Kim k-E, MMK k- $-\varepsilon$, Explicit Algebraic Reynolds Stress Model (EARSM), and Large Eddy Simulation (LES) in Wall-Adapting Local Eddy-viscosity (WALE), for the numerical; simulation. They concluded that the slighter change in the quantity of addition of KCI solution affects the fluid flow behavior [7-18]. The numerical simulation and scaled water model are performed as an experimental simulation of the four-strand tundish with different flow modifier configurations. They concluded that the tundish configuration with flow modifiers show better fluid flow and inclusion removal, and the bare tundish was prostrate short-circuiting [19-25]. The numerical and experimental simulation is performed on 3-strands tundish with and without flow modifiers. They concluded that flow modifier deployment results in better fluid flow and promotes inclusion removal, eventually outputs more cleanliness in steel [24-29]. The fluid flow simulation is performed in two different tundish configurations as single-strand and three strands tundish with flow modifiers. The numerical simulation was performed through ANSYS FLUENT 14.0 and experimental through water model method comprising tracer injection for RTD curves evaluation. They concluded that utilization of flow modifiers resulted in better RTD and inclusion removal, but some caused an increase in dead volume fraction [28-32]. The authors performed fluid flow analyses on tundish with different flow modifiers configurations through ANSYS FLUENT 14.0 and the water model method. The flow modifiers utilized were a dam, baffle, and turbulence inhibiter (TI), and it is concluded that the tundish with turbulence inhibiter (TI) comprises a better level of inclusion removal than others [30]. The five-strand bloom tundish is utilized with five baffles and two types of turbulence inhibitors (TIs) investigated through a metaphysical model for fluid flow behavior and RTD curves. It was concluded that there is a decrease in residence time, increase in inclusion removal efficiency and consistency in the strands of the tundish due to utilization of flow modifiers [31-48]. Sheng Chang et al. have performed fluid flow analysis of delta shape tundish through full-scale water model, with microbubbles injection in the ladle strand. The impact pad is also deployed for achieving enhancements in the fluid flow and inclusion removal. It was concluded that there was an increase in inclusion removal due to the dispersion of the micro-bubbles [49-67].

\section{Materials and Methods}

\subsection{Numerical simulation.}

This study focuses on the molten metal flow in the tundish, which is simulated through utilizing the ANSYS FLUENT 19.2 software (commercial package). The geometry model of tundish with boundary conditions and geometry features used in the numerical simulation is shown in Figure 1. These boundary conditions are the inlet, outlet, and the tundish walls, which are considered in the numerical simulation. A symmetry plane is also utilized at the vertical longitudinal direction of tundish for exhibiting the inlets and outlet locations. 


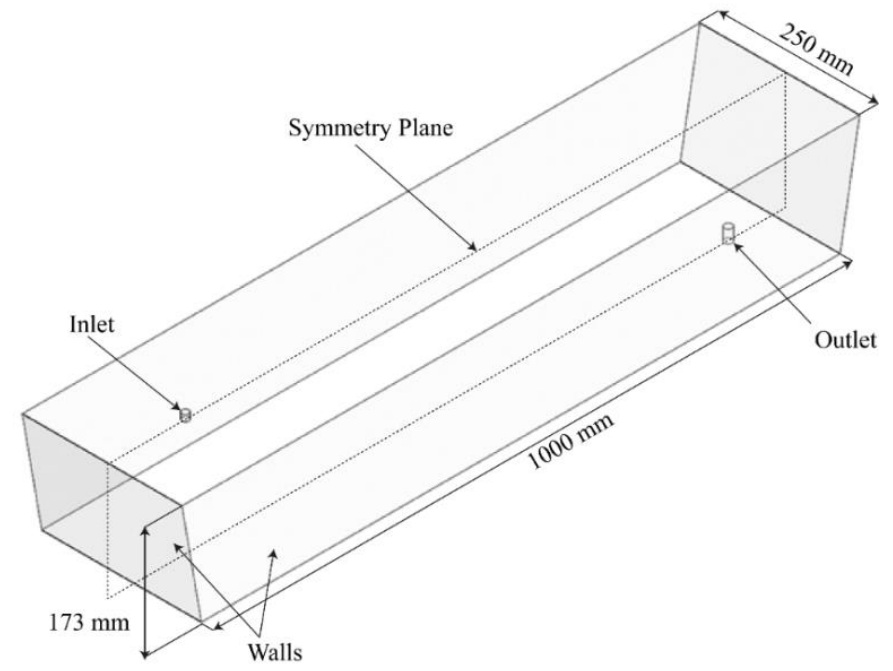

Figure 1. Boundary conditions and dimensions of tundish.

The water level (tundish height) in the tundish is $173 \mathrm{~mm}$; the length is $1000 \mathrm{~mm}$, and the width is $250 \mathrm{~mm}$. The inlet and outlet cross-sectional diameter are $12 \mathrm{~mm}$, and the area is $113.097 \mathrm{~mm}^{2}$. The tundish also has a $15^{\circ}$ draft with a lower surface. The other boundary conditions comprise the inlet velocity of $2 \mathrm{~m} . \mathrm{s}^{-1}$ and flowrate of $0.2 \mathrm{Kg} . \mathrm{s}^{-1}$. Reynolds-Averaged Navier-Stokes (RANS) modeling is utilized for the numerical simulation [51]. The realizable $\mathrm{k}-\varepsilon$ model and the SIMPLEC algorithm (with a second-order scheme) are applied for numerical simulation [52]. The assumptions deployed during the simulation are isothermal conditions and transient during the tracer injection process. The fluid phenomena description in this study is presented by following basic continuity equations:

$$
\begin{gathered}
\nabla(\rho u)=0 \\
\nabla(\rho u u)=-\nabla p+\nabla\left(\overline{\bar{t}}_{\text {eff }}\right)+\rho g \\
\bar{t}_{\text {eff }}^{=}=\left(\mu+\mu_{\mathrm{t}}\right)\left[\left(\nabla u+\nabla u^{\mathrm{T}}\right)-\frac{2}{3} \nabla u l\right]
\end{gathered}
$$

Where $\rho$ : density in $\mathrm{kg} \cdot \mathrm{m}^{-3}, u$ : velocity in $\mathrm{m} . \mathrm{s}^{-1}$, t: time in $\mathrm{s}, \mathrm{g}$ : gravitational acceleration in $\mathrm{m} . \mathrm{s}^{-}$ ${ }^{2}$, T: fluid temperature in $\mathrm{K}, \mu$ : dynamic viscosity in $\mathrm{kg} \cdot \mathrm{m}^{-1} \cdot \mathrm{s}^{-1}, \mu_{\mathrm{t}}$ : turbulent viscosity in $\mathrm{kg} \cdot \mathrm{m}^{-}$

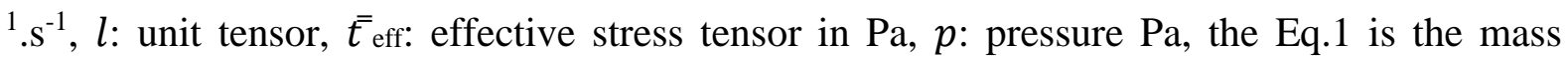
conservation equation, Eq. 2 is the momentum conservation, and Eq. 3 depicts the effective stress tensor.

\subsection{Tracer injection simulation and RTD analysis.}

The RTD curves of the tundish in the presence and absence of flow modifiers are analyzed. Tracer comprising similar properties as domain fluid is introduced at the inlet, and the variation in the amount of tracer with respect to time is monitored at the output after 3 seconds. After examining the steady-state flow, the tracer injection through the transient mode's species transport model is numerical simulation. Further, for 20 minutes, the tracer injection is discontinued, and only the domain fluid characteristics are examined. The flow characterization comprises the initial step of evaluating the dimensionless C-curve for tundish is derived in the following [53-54]:

The dimensionless time, $\theta$, was calculated as Eq. 4:

$$
\theta=\frac{t}{\bar{t}}
$$

where $\bar{t}$ is the theoretical mean residence time as Eq. 5: 


$$
\bar{t}=\frac{v}{Q}
$$

The dimensionless concentration of strand i (the outflow at outlet i) can be calculated as Eq. 6:

$$
C_{\mathrm{i}}=\frac{c \mathrm{i} \mathrm{V}}{M}
$$

where V: complte volume, $\mathrm{Ci}$ : concentration, and $\mathrm{M}$ : the amount of tracer injected.

Consequently; mean residence time of flow, tmean, is calculated as Eq. 7:

$$
t_{\text {mean }}=\frac{\int_{0}^{\infty} t C(t) d t}{\int_{0}^{\infty} C(t) d t}
$$

In the instant step, the tundish performance is classed by separating the flow volumes into three types: the plug flow $\left(\mathrm{V}_{\mathrm{p}}\right)$, the well-mixed volume $\left(\mathrm{V}_{\mathrm{m}}\right)$, and the dead volume $\left(\mathrm{V}_{\mathrm{d}}\right)$ as Eq. 8 to 10 :

$$
\begin{gathered}
\mathrm{V}_{\mathrm{p}}=\theta_{\text {min }} \\
\mathrm{V}_{\mathrm{d}}=1-\frac{Q a}{Q} \times \theta_{\text {mean }} \\
\mathrm{V}_{\mathrm{m}}=1-\mathrm{V}_{\mathrm{p}}-\mathrm{V}_{\mathrm{d}}
\end{gathered}
$$

\subsection{Experimental simulation setup.}

The water modeling system setup utilized for analyzing and investigating the tracer injection and the RTD is shown schematically in Figure 2. This system comprises a water feeding system along with a solenoid valve tracer injector. Usually, the tracer is introduced in the flow-through syringe, which affects the domain fluid velocity. The solenoid valve system provides a way to feed water, and also, after shifting, the tracer is feed into the tundish. The physical tracer structure comprises $70 \mathrm{ml}$ of water, $9 \mathrm{~g}$ of $\mathrm{NaCl}$ (potassium chloride), and 10 $\mathrm{ml}$ of red-colored dye. The electric conductivity meter is deployed at the outlet for measuring the tracer concentration about every single second. Flowmeter is deployed before the solenoid system for monitoring and regulating the flow rate of feed water.

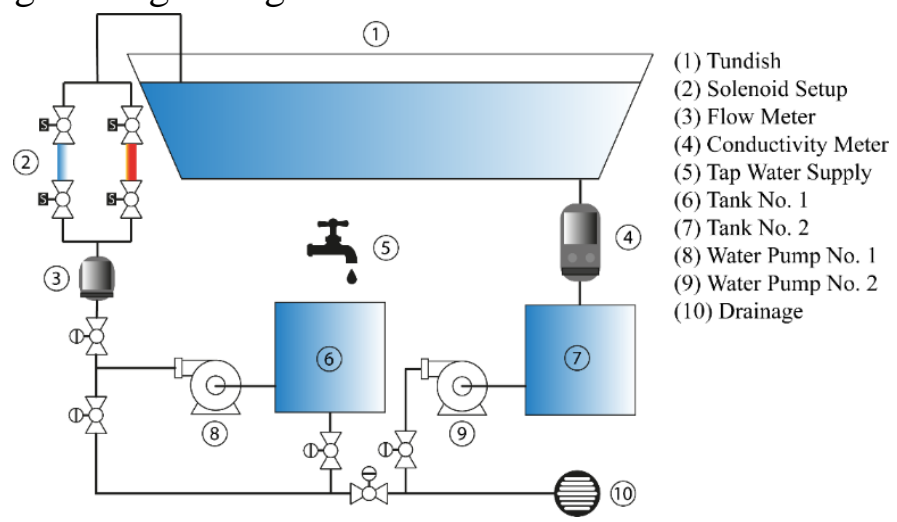

Figure 2. Schematic diagram of water modeling system setup.

\subsection{Flow modifiers.}

The tundish configurations comprise three different flow modifiers and bare tundish, which are tundish with the dam, baffle, and turbulence inhibiter (TI). The dam consists of 100 $\mathrm{mm}$ height and $15 \mathrm{~mm}$ thickness. It is located at the center of the tundish. The baffle has 15 $\mathrm{mm}$ thickness and 9 holes of $30 \mathrm{~mm}$ diameter; it is also located at the center. The TI consists of rectangular dimensions as $120 \times 120 \times 30 \mathrm{~mm}^{3}$, which is located below the inlet. These tundish configurations are shown in Figure 3 (a-d). 


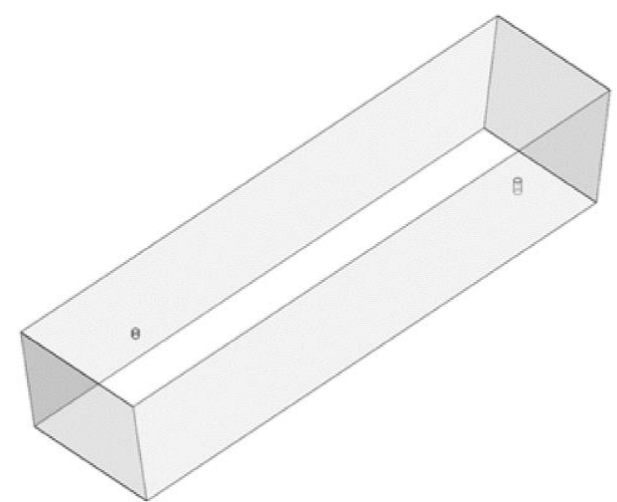

(a)

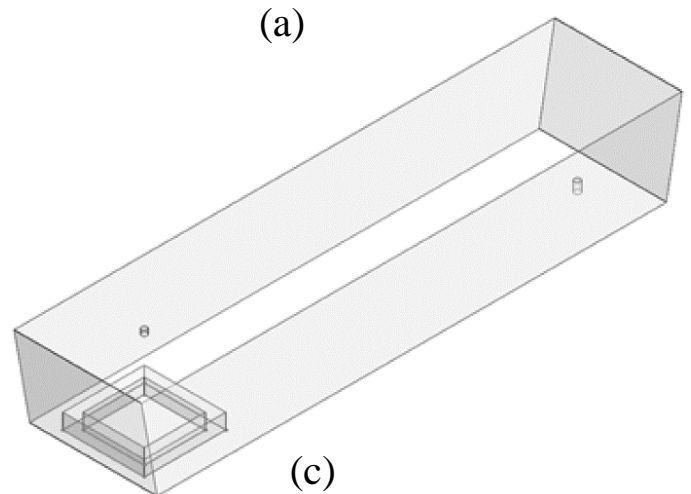

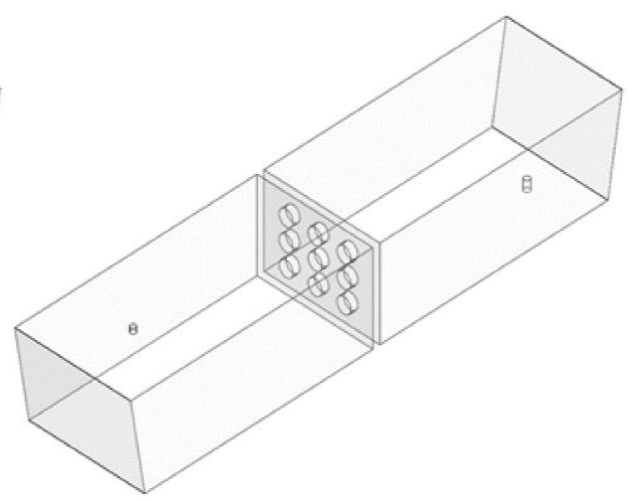

(b)

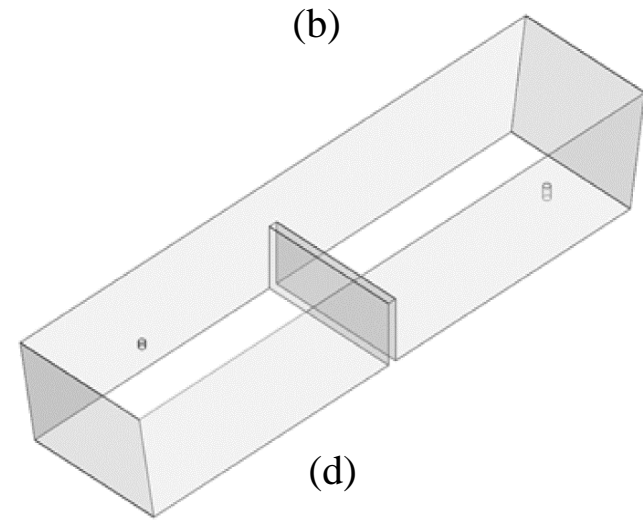

Figure 3. Tundish configurations with the flow modification: (a) bare tundish; (b) baffle; (c) TI; (d) dam.

\section{Results and Discussion}

\subsection{Path-lines of particle and turbulence kinetic energy.}

The random injection of sampling particles comprising similar fluid properties, through the which the path-lines of fluid flow in tundish is simulated. The path-lines of particles in the tundish fluid flow with bare tundish, dam, baffle, and TI are shown in Figure 4 (a-d). The color variation of different particles shows the fluid flow pattern from beginning to end. In the bare tundish configurations, counter-rotating toroidal vortices presence at the inlet is observed, and there is gradual disappearance after flowing towards the outlet.
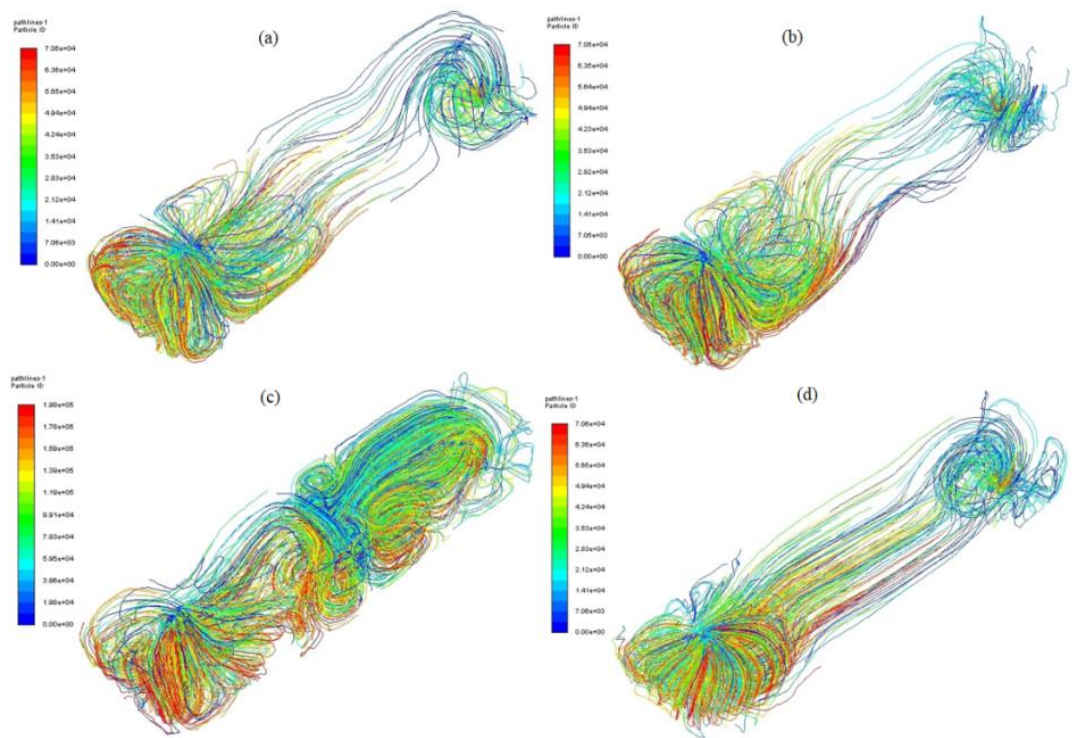

Figure 4. Path-lines of particles in the fluid flow of (a) bare tundish; (b) dam; (c) baffle; (d) TI. 
There is a change in the fluid flow after the fitment of the dam or baffle. In the case of a tundish with a dam, the swirls have occurred on both sides of the dam. The fluid flow contains fewer vortices after flowing through the baffle. In the tundish with TI configurations, the vortices only occur near the TI.

The turbulence kinetic energy of the particle path-lines in the different configurations of tundish is shown in Figure 5 (a-d). It can be observed that the flow modifier, particularly TI switches the nature of the turbulence. The high turbulence kinetic energy is encountered at the inlet zone. Bare tundish comprises a dam, baffle, and high turbulence zone initiated at the inlet zone and flourishes until the half section of the tundish. In the case of tundish with TI, the high turbulence zone is acute at the TI and humbler in other zones as compared to others.

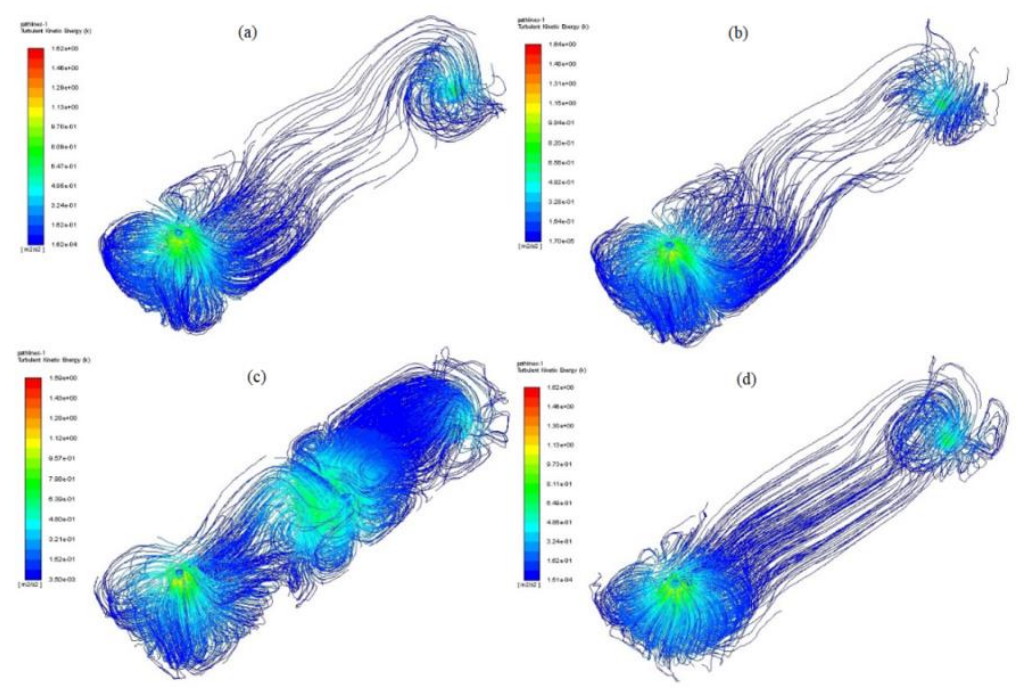

Figure 5. Path-lines of the turbulence kinetic energy in the fluid flow of (a) bare tundish; (b) dam; (c) baffle; (d) TI.

\subsection{RTD curves.}

Figure 6 (a) and (b) show the simulation results and PWM results of RTD curves for the respective tundish model. The residence time curves comprise curves of dimensionless mass fraction of the tracer against dimensionless time $(\Theta)$. The $\theta_{\text {start }}, t_{\text {start }}, \theta_{\max }, t_{\max }, \theta_{\text {mean }}, t_{\text {mean }}$ of the RTD curves, plug volume $\left(\mathrm{V}_{\mathrm{p}}\right)$, well-mixed volume $\left(\mathrm{V}_{\mathrm{m}}\right)$, and dead volume $\left(\mathrm{V}_{\mathrm{d}}\right)$ from simulation and water model experiment, which are also fundamental indicants for the flow characterization, are summed in Tables 1 and 2. Good agreement between the CFD simulation results and the experiment results is encountered.

(a)
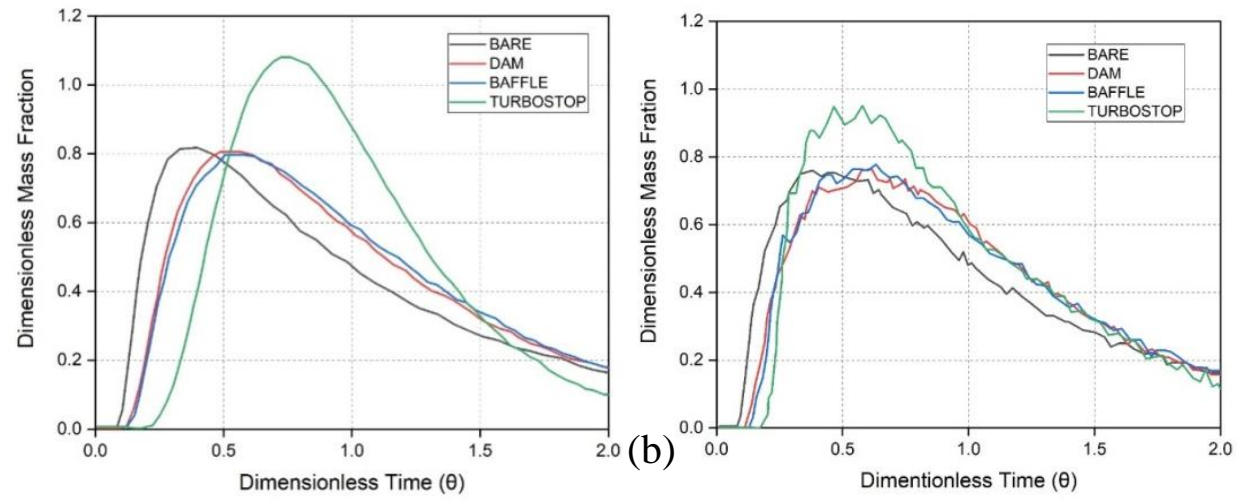

Figure 6. (a) Simulation and (b) experimental results of RTD curves for respective tundish model. 
Table 1. Important terms of RTD curves and fraction flow data extracted from the CFD simulation results.

\begin{tabular}{|c|c|c|c|c|c|c|c|c|c|}
\hline \multirow[b]{2}{*}{ Configuration } & \multicolumn{6}{|c|}{ Residence Time Indicators } & \multirow[b]{2}{*}{$\begin{array}{l}\left(\mathbf{V}_{\mathbf{p}}\right) \\
(\%)\end{array}$} & \multirow[b]{2}{*}{$\begin{array}{c}\left(\mathbf{V}_{\mathbf{m}}\right) \\
(\boldsymbol{\%})\end{array}$} & \multirow[b]{2}{*}{$\begin{array}{l}\left(\mathbf{V}_{\mathbf{d}}\right) \\
(\%)\end{array}$} \\
\hline & $\theta_{\text {Start }}$ & $\begin{array}{l}\mathbf{t}_{\text {start }} \\
\text { (sec) }\end{array}$ & $\theta_{\text {Max }}$ & $\begin{array}{l}\mathbf{t}_{\text {(Max) }} \\
(\mathrm{sec})\end{array}$ & $\boldsymbol{\theta}_{\text {Mean }}$ & $\begin{array}{l}\mathbf{t}_{\text {(Mean) }} \\
\text { (sec) }\end{array}$ & & & \\
\hline Bare & 0.09 & 21 & 0.37 & 94 & 0.84 & 213 & 9.20 & 64.60 & 27.80 \\
\hline Dam & 0.11 & 33 & 0.52 & 134 & 0.94 & 222 & 11.20 & 66.20 & 18.70 \\
\hline Baffle & 0.12 & 30 & 0.40 & 106 & 0.96 & 232 & 12.54 & 69.74 & 18.50 \\
\hline TI & 0.19 & 52 & 0.71 & 192 & 0.93 & 241 & 19.95 & 71.90 & 8.74 \\
\hline
\end{tabular}

After observing Tables 1 and 2, it is found that after implantation of the flow modifiers, there are improvements in the flow time indicators. There is 2 times improvement in $\theta_{\text {start }}$ after deploying TI, which furnishes optimal flow characteristics. There are $10 \%$ improvements in all the tundish configurations mean residence time ( $t_{\text {mean }}$ and $\theta_{\text {mean }}$ ). This result forbids the short-circuit flows and advances the floatation of inclusions. There area decrease and improvement in percentage fractions of stagnant flow or $\mathrm{V}_{\mathrm{d}}$ after implementing these flow modifiers.

Table 2. Important terms of RTD curves and fraction flow data extracted from the PWM experiment results.

\begin{tabular}{|c|c|c|c|c|c|c|c|c|c|}
\hline \multirow[b]{2}{*}{ Configuration } & \multicolumn{6}{|c|}{ Residence Time Indicators } & \multirow{2}{*}{$\begin{array}{l}\left(\mathbf{V}_{\mathbf{p}}\right) \\
(\%)\end{array}$} & \multirow{2}{*}{$\begin{array}{c}\left(\mathbf{V}_{\mathbf{m}}\right) \\
(\boldsymbol{\%})\end{array}$} & \multirow{2}{*}{$\begin{array}{l}\left(\mathbf{V}_{\mathbf{d}}\right) \\
(\%)\end{array}$} \\
\hline & $\theta$ Start & $\begin{array}{l}\text { tstart } \\
\text { (sec) }\end{array}$ & $\theta_{\text {Max }}$ & $\begin{array}{l}\mathbf{t}_{\text {(Max) }} \\
\text { (sec) }\end{array}$ & $\theta_{\text {Mean }}$ & $\begin{array}{c}\mathbf{t}_{(\text {Mean })} \\
\text { (sec) }\end{array}$ & & & \\
\hline Bare & 0.08 & 22 & 0.43 & 125 & 0.85 & 212 & 8.21 & 64.97 & 27.22 \\
\hline Dam & 0.13 & 30 & 0.63 & 156 & 0.91 & 224 & 12.54 & 69.03 & 18.85 \\
\hline Baffle & 0.13 & 36 & 0.55 & 147 & 0.91 & 227 & 12.90 & 67.74 & 17.95 \\
\hline TI & 0.17 & 48 & 0.54 & 150 & 0.88 & 228 & 18.87 & 65.16 & 15.98 \\
\hline
\end{tabular}

\section{Conclusions}

The PWM experiment and the CFD numerical simulation are expended to prognosticate flow behavior and investigate the tundish flow characteristics. The deployment of a flow modifier is intended to improve the flow behavior in tundish models. The reduction of shortcircuiting of flows and improvement in RTD results in better inclusion removal in tundish operation. Default meshing was deployed for the CFD simulation, and better amalgamation with PWM was achieved. In the case of PWM experiments and CFD simulation with tracer injection, there is an improvement of more than $20 \%$ in the peak $\left(\theta_{\max }\right.$ and $\left.t_{\max }\right)$ and the minimum residence time $\left(\theta_{\text {start }}\right.$ and $\left.t_{\text {start }}\right)$ of RTD curves. Among the entire tundish configuration in this research, the tundish with TI provides optimal flow characteristics and eventually promotes a better inclusion removal level.

\section{Funding}

This research received no external funding.

\section{Acknowledgments}

Jaywant N. Yadav gratefully thanks Dr. D. K. Rajak, Assistant Professor, Department of Mechanical Engineering, at Sandip Institute of Technology and Research Centre, Nashik, to go through the manuscript providing valuable comments and suggestions for improving the quality of this work.

\section{Conflicts of Interest}

The authors declare no conflict of interest. 


\section{References}

1. Moumtez, B.; Ahmed, B.; Kamel, T. Numerical investigation of the fluid flow in continuous casting tundish using analysis of RTD curves. Journal of Iron and Steel Research International, 2009, 16, 22-29, https://doi.org/10.1016/S1006-706X(09)60022-4.

2. Kumar, A.; Satish, C.; Koria; Mazumdar, D. An assessment of fluid flow modelling and residence time distribution phenomena in steelmaking tundish systems. ISIJ International, 2004, 44, 1334-1341, https://doi.org/10.2355/isijinternational.44.1334.

3. Qu, T.; Cheng-jun, L.; Jiang, M. Numerical simulation for effect of inlet cooling rate on fluid flow and temperature distribution in tundish. Journal of Iron and Steel Research, International, 2012, 19, 12-19, https://doi.org/10.1016/S1006-706X(12)60107-1.

4. Rodolfo, D.; Morales, Manuela D.; Jorge, P.; Simon, L.; Jose, D. Modelling steel flow in a three-strand billet tundish using a turbulence inhibitor. Process Metallurgy, 2001, 72, 11-16, https://onlinelibrary.wiley.com/doi/abs/10.1002/srin.200100074.

5. Ralf, B.; Hans, J.; Odenthal, Herbert, P. Transient fluid flow in a continuous casting tundish during ladle change and steady-state casting. Process Metallurgy, 2016, 76, 71-80, https://doi.org/10.1002/srin.200505975.

6. Morales, R.; Barreto, J.; Lopez-Ramirez, S.; Palafox-Ramos, J.; Diaz-Cruz, M. Mathematical simulation of the influence of buoyancy forces on the molten steel flow in a continuous casting tundish. Modelling Simulation in Material Science and Engineering, 2000, 8, 781-801, https://iopscience.iop.org/article/10.1088/0965-0393/8/6/302/pdf.

7. Chao, C.; Lage, T.; Anders, T.; Guoguang, C.; Jonsson, P. A mathematical modeling study of the influence of small amounts of $\mathrm{KCl}$ solution tracers on mixing in water and residence time distribution of tracers in a continuous flow reactor-metallurgical tundish. Chemical Engineering Science, 2015, 137, 914-937, https://doi.org/10.1016/j.ces.2015.07.037.

8. Artemov,V.; Beale, S.; Davis, G.; Escudier, M.; Fueyo, N.; Launder, B.; Leonardi, E.; Malin, M.; Minkowycz, W.; Patankar, S.; Pollard, A.; Rodi, W.; Runchal, A.; Vanka, S. A tribute to D. B. spalding and his contributions in science and engineering. International Journal of Heat and Mass Transfer, 2009, 52, 3884-3905, https://doi.org/10.1016/j.ijheatmasstransfer.2009.03.038.

9. Beinhorn, M.; Dietrich, P.; Kolditz, O.; 3-D numerical evaluation of density effects on tracer tests. Journal of Contaminant Hydrology, 2005. 81, 89-105, https://doi.org/10.1016/j.jconhyd.2005.08.001.

10. Bujalski, J.; Jaworski, Z.; Bujalski, W.; Nienow, A. The influence of the addition position of a tracer on CFD simulated mixing times in a vessel agitated by a RUSHTON turbine. Chemical Engineering Research and Design, 2002, 80, 824-831, https://doi.org/10.1205/026387602321143354.

11. Burman, J.; Jonsson, L. Issues when linking computational fluid dynamics for urban modeling to toxic load models: The need for further research. Atmospheric Environment, 2015, 104, 112-124, https://doi.org/10.1016/j.atmosenv.2014.12.068.

12. Chattopadhyay, K.; Mihaiela, I.; Roderick, I. L. Guthrie. Physical and mathematical modelling of steelmaking tundish operations: A review of the last decade (1999-2009). ISIJ International, 2010, 50, 331348, https://doi.org/10.2355/isijinternational.50.331.

13. Chaudhary, R.; Thomas, C.; Vanka, S. Transient turbulent flow in a liquid-metal model of continuous casting, including comparison of six different methods. Metallurgical and Materials Transactions B, 2011, 42B, 987-1007, https://link.springer.com/article/10.1007/s11663-011-9526-1.

14. Chao, C.; Guoguang, C.; Haibo, S.; Zibing, H.; Xinchao, W.; Jiaquan, Z. Effects of salt tracer amount, concentration and kind on the fluid flow behavior in a hydrodynamic model of continuous casting tundish. Steel research int., 2012, 83, 1141-1151, https://doi.org/10.1002/srin.201200086.

15. Chao, C.; Jonsson, L.; Anders, T.; Guoguang, C.; Jonsson, P. A mathematical modeling study of tracer mixing in a continuous casting tundish. Metallurgical and Materials Transactions, 2014, 46, 169-190, https://doi.org/10.1007/s11663-014-0190-0.

16. Xin, F.; Jingcai, C.; Xiangyang, L.; Chao, Y.; Zai-Sha, M. Numerical simulation of turbulent flow in a baffled stirred tank with an explicit algebraic stress model. Chemical Engineering Science, 2012, 69, 30-44, https://doi.org/10.1016/j.ces.2011.09.055.

17. Kolhe, N.; Mirage, Y.; Patwardhan, A.; Rathod, V.; Pandey, N.; Kamachi, U.; Natarajan, R. CFD and experimental studies of single-phase axial dispersion coefficient in pulsed sieve plate column. Chemical Engineering Research and Design, 2011, 89, 1909-1918, https://doi.org/10.1016/j.cherd.2011.01.020. 
18. Masood, R.; Delgado, A. Numerical investigation of the inter phase forces and turbulence closure in 3D square bubble columns. Chemical Engineering Science, 2014, 108, 154-168, https://doi.org/10.1016/j.ces.2014.01.004.

19. Masood, R.; Rauh, C.; Delgado, A. CFD simulation of bubble column flows: An explicit algebraic Reynolds stress model approach. International Journal of Multiphase Flow, 2014. 66, 11-25. https://doi.org/10.1016/j.ijmultiphaseflow.2014.06.008.

20. Cloete, J.; Akdogan, G.; Bradshaw, S.; Chibwe, D. Physical and numerical modelling of a four-strand steelmaking tundish using flow analysis of different configurations. The Journal of The Southern African $\begin{array}{lllll}\text { Institute } \quad \text { Mining and } & \text { Metallurgy, }\end{array}$ http://www.scielo.org.za/scielo.php?script=sci_arttext\&pid=S2225-62532015000500008.

21. Jha, P.; Srinivasa Rao, P.; Dewan, A. Effect of height and position of dams on inclusion removal in a sixstrand tundish. ISIJ International, 2008, 48, (2) 154-160, https://doi.org/10.2355/isijinternational.48.154

22. Kumar, A.; Mazumdar, D.; Koria, S. Modeling of fluid flow and residence time distribution in a four-strand tundish for enhancing inclusion removal. ISIJ International, 2008, 48, 38-47, https://www.jstage.jst.go.jp/article/isijinternational/48/1/48_1_38/_article.

23. Mishra, S.; Jha, P.; Sharma, S.; Ajmani, S. Effect of blockage of outlet nozzle on fluid flow and heat transfer in continuously cast multistrand billet caster tundish. Canadian Metallurgical Quarterly, 2012, 51, 170-183, https://doi.org/10.1179/1879139511Y.0000000032.

24. Tripathi, A.; Kumar, S.; Ajmani, S. Effect of shape and flow control devices on the fluid flow characteristics in three different industrial six strand billet caster tundish. ISIJ International, 2011, 51, 1647-1656, https://www.jstage.jst.go.jp/article/isijinternational/51/10/51_10_1647/_article.

25. Song-Xia, L.; Xue-Min, Y.; Lin, D.; Liang, L.; Cheng-Zhi, L. Hydrodynamic and mathematical simulations of flow field and temperature profile in an asymmetrical t-type single-strand continuous casting tundish. ISIJ International, 2008, 48, 1712-1721, https://doi.org/10.2355/isijinternational.48.1712.

26. Kowitwarangkul, P.; Kamonrattanapisud, M.; Ekachai, J. CFD simulation of molten steel flow with isothermal condition in the continuous casting tundish. KMUTNB International Journal of Applied Science and Technology, 2016, 9, 71-77, http://ojs.kmutnb.ac.th/index.php/ijst/article/view/572.

27. Warzecha, M. Numerical and physical modelling of steel flow in a one-strand continuous casting tundish. METALURGIJA, 2011, 50, 147-150. https://www.researchgate.net/publication/49966107.

28. Ansys Fluent theory guide 14.0, ANSYS, Inc. Release 14.0, Southpointe, 2011, https://www.scribd.com/doc/140163341/Ansys-Fluent-14-0-Theory-Guide.

29. Kowitwarangkul, P.; Harnsihacacha, A. Tracer injection simulations and RTD analysis for the flow in 3strands steelmaking tundish. Key Engineering Materials, 2017, 728, 72-77, https://doi.org/10.4028/www.scientific.net/KEM.728.72.

30. Harnsihacacha, A.; Piyapaneekoon, A.; Kowitwarangkul, P. Physical water model and CFD studies of fluid flow in a single strand tundish. Materials Today: Proceedings, 2018, 5, 9220-9228, https://doi.org/10.1016/j.matpr.2017.10.093.

31. Qing, F.; Hua, Z.; Ronghua, L.; Chao, L.; Wang, Y.; Hongwei, N. Optimization of flow, heat transfer and inclusion removal behaviors in an odd multistrand bloom casting tundish, Journal of Materials Research and Technology, 2020, 9, 347-363, https://doi.org/10.1016/j.jmrt.2019.10.064.

32. Qiao, J.; Wang, D.; Xiaozhou, D.; Zheng, N.; Chiu, S.; Maze, A. AR-maze: A tangible programming tool for children based on technology. Proceedings of the $17^{\text {th }}$ ACM Conference on Interaction Design and Children, 2018, IDC, 611-616, https://doi.org/10.1145/3202185.3210784.

33. Shu-guo, Z.; Miao-yong, Z. Optimization of flow control devices in a ten-strand billet caster tundish. China Foundry, 2016, 13, 414-421, https://doi.org/10.1007/s41230-016-6082-y.

34. Merder, T. Modelling the influence of changing constructive parameters of multi-strand tundish on steel flow and heat transfer. Ironmaking \& Steelmaking, 2016, 43, 758-768, https://www.tandfonline.com/doi/full/10.1080/03019233.2016.1209825.

35. Sheng, C.; Wenxin, H.; Baokuan, L.; Roderick, I.; Guthrie, L. Motion behavior of micro-bubbles in a delta shape tundish using impact pad. Powder Technology, 2020, 367, 296-304, https://doi.org/10.1016/j.powtec.2020.03.051.

36. Martin, H.; Amjad, A.; Rudiger, S. Collision of micro-sized non-metallic inclusions in liquid steel flows: a computational study. Multiphase Flows in Materials Processing, 2018, 70, 2943-2949, https://doi.org/10.1007/s11837-018-3113-8. 
37. Xiaodong, Z.; Dapeng, Z.; Jincheng, S.; Cong, W.; Hiroyuki, M. An integrated study on the evolution of inclusions in EH36 shipbuilding steel with mg addition: from casting to welding. Metallurgical Processes Workshop for Young Scholars, 2017, 49, 481-489, https://doi.org/10.1007/s11663-017-1163-x.

38. Yaowen, X.; Yijun, C. Effect of bubble size on bubble-particle attachment and film drainage kinetics- A theoretical study. Powder Technology, 2017, 322, 140-146, https://doi.org/10.1016/j.powtec.2017.09.007

39. Boris, A.; Bogale, T.; Laurence, D.; Xianglin, Y. Influence of bubble approach velocity on liquid film drainage between a bubble and a spherical particle. Powder Technology, 2018, 388, 140-144, https://www.sciencedirect.com/science/article/abs/pii/S0032591018305096?via\%3Dihub.

40. Asad, A.; Haustein, M.; Chattopadhyay, K.; Aneziris, C.; Schwarze, R. Numerical assessment of a filtration experiment influenced by microscale carbon monoxide bubbles arising in steel melt. Multiphase Flows in Materials Processing, 2018, 70, 2927-2933. https://doi.org/10.1007/s11837-018-3117-4.

41. Sheng, C.; Liangcai, Z.; Zongshu, Z. Simulation of flow and heat fields in a seven-strand tundish with gas curtain for molten steel continuous-casting. ISIJ International, 2015, 55, 834-844, https://doi.org/10.2355/isijinternational.55.837.

42. Gregory, L,; Ryoichi, Y,; Uwe, H,; Takashi, T. Direct numerical simulation of a particle attachment to an immersed bubble. Physics of Fluids, 2016, 28, https://doi.org/10.1063/1.4960627.

43. Duan, H.; Scheller, P.; Ying, R.; Zhang, L. Fluid flow and inclusion behavior around spherical-cap bubbles, CFD modeling and simulation in materials processing. The Minerals, Metals \& Materials Society, 2019, 71. https://doi.org/10.1007/s11837-018-3193-5.

44. Ireland, P.; Jameson, G. Collision of a rising bubble-particle aggregate with a gas-liquid interface, International Journal of Mineral Processing, 2014, 130, 1-7. https://doi.org/10.1016/j.minpro.2014.05.002.

45. Holzinger, G.; Thumfart, M. Flow interaction in continuous casting tundish due to bubble curtain operation. Steel Research Int. 2019, 90. https://onlinelibrary.wiley.com/doi/abs/10.1002/srin.201800642.

46. Chatterjee, S.; Donghui, L.; Chattopadhyay, K. Modeling of liquid steel/slag/argon gas multiphase flow during tundish open eye formation in a two-strand tundish. Metallurgical and Materials Transactions, 2018, 49, 756-766. https://doi.org/10.1007/s11663-018-1177-z.

47. Sheng, C.; Xiangkun, C.; Zongshu, Z.; Mihaiela, I,; Roderick, I. Micro-bubble formation under non-wetting conditions in a full-scale water model of a ladle shroud/tundish system. ISIJ International, 2018, 58, 60-67. https://www.jstage.jst.go.jp/article/isijinternational/58/1/58_ISIJINT-2017-390/_article.

48. Sheng, C,; Xiangkun, C,; Zongshu, Z. Regimes of micro-bubble formation using gas injection into ladle shroud. Metallurgical and Materials Transactions B, 2018, 49, 953-957. https://doi.org/10.1007/s11663018-1231-x.

49. Hoppe, F.; Breuer, M. A deterministic and viable coalescence model for euler-lagrange simulations of turbulent microbubble-laden flows. International Journal of Multiphase Flow, 2017, 99, 213-230, https://doi.org/10.1016/j.ijmultiphaseflow.2017.10.009.

50. Álvaro, M.; Maddalena, T.; Fraters, A.; Devaraj, M.; Detlef, L. Coalescence of diffusively growing gas bubbles. Journal of Fluid Mechanics, 2018, 846, 143-165, https://doi.org/10.1017/jfm.2018.277.

51. Maulik, R.; Sharma, H.; Patel, S.; Lusch, B.; Jennings, E. A turbulent eddy-viscosity surrogate modeling framework for reynolds-averaged navier-stokes simulations. Computers and Fluids, 2020, https://doi.org/10.1016/j.compfluid.2020.104777.

52. Tsan-Hsing, S.; William, W.; Liou, A.; Zhigang, Y.; Jiang, Z. A new k- $\varepsilon$ eddy viscosity model for high reynolds number turbulent flows. Compurers Fluids, 1995, 24, 227-238, https://doi.org/10.1016/00457930(94)00032-T.

53. Sahai Y.; Emi, T. Tundish technology for clean steel production, World Scientific Publishing Co. Pte. Ltd., 2008, https://doi.org/10.1142/6426.

54. Yadav, J,; Singh, N. Production of metal production in casting through tundish: A review.Gorteria Journal, 2020, 33, 355-376, https://gorteria.com/wp-content/uploads/2020/12/GRTJ-P560.36-F.pdf.

55. Jose, R.; de Sousa, R.; de Souzaa, E.; Francisco, M.; Jose, A. Modeling and computational simulation of fluid flow, heat transfer and inclusions trajectories in a tundish of a steel continuous casting machine. JMRTec, 2019, 374, 4209-4220, https://doi.org/10.1016/j.jmrt.2019.07.029.

56. Xufeng, Q.; Changgui, C.; Chunming, Z.; Jinlei, Z.; Yan, Jin. A simulation study on the flow behavior of liquid steel in tundish with annular argon blowing in the upper nozzle. Metals, 2019, 9, 225, 1-19, https://doi.org/10.3390/met9020225. 
57. Yazdi, M.; Khorasani, A.; Talebi, S. Experimental investigation of flow control devices effect on inclusion separation in a four strand tundish. Canadian Metallurgical Quarterly, 2019, 58, 1-10, https://doi.org/10.1080/00084433.2019.1590039.

58. Jun, H.; Zhigang, Y.; Shaoyuan, S.; Baofeng, W.; Chi, L. Flow characteristics for two-strand tundish in continuous slab casting using PIV. Metals, 2019, 9,1-10, https://doi.org/10.3390/met9020239.

59. Fei, X.; Shuguo, Z.; Zonghui, L.; Miaoyong, Z. Flow field, temperature field, and inclusion removal in a new induction heating tundish with bent channels. Metals, 2019, 9, 1-16, https://doi.org/10.3390/met9050561.

60. Cwudzi, A. Influence of subflux turbulence controller and ladle shroud asymmetric using on hydrodynamic conditions in one strand slab tundish. Metals, 2019, 9, 1-13, https://doi.org/10.3390/met9010068.

61. Xingrun, C.; Guoguang, C.; Yuyang, H.; Jingyu, L. Oxide-inclusion evolution in the steelmaking process of 3041 stainless steel for nuclear power, Metals, 2019, 9, 1-11, https://doi.org/10.3390/met9020257.

62. Yang, B.; Lei, H.; Zhao, Y.; Guocheng, X.; Zhang, H. Quasi-symmetric transfer behavior in an asymmetric two-strand tundish with different turbulence inhibitor, Metals, 2019, 9, 1-15, https://doi.org/10.3390/met9080855.

63. Feng, W.; Daoxu, L.; Wei, L.; Shufeng, Y.; Jingshe, Li. Reoxidation of al-killed steel by $\mathrm{Cr}_{2} \mathrm{O}_{3}$ from tundish cover flux, Metals, 2019, 9, 1-11, https://doi.org/10.3390/met9050554.

64. Siddiqui, M.; Man-Hoe, K. Two-phase numerical modeling of grade intermixing in a steelmaking tundish, Metals , 2019, 9, 1-14, https://doi.org/10.3390/met9010040.

65. Lei, C.; Jun-song, C.; Yu-qian, L.; She-bin, W.; Chao, C. Effects on the fluid flow in a metallurgical tundisha cfd model study, 2020, International Conference on Energy, Environment and Bioengineering (ICEEB 2020) 2020, 185, https://doi.org/10.1051/e3sconf/202018504069.

66. Dong-Yuan, S. Mathematical modelling of multiphase flow and inclusion behavior in a single-strand tundish. Metals, 2020, 10, https://doi.org/10.3390/met10091213.

67. Marketa, T.; Ckova, J.; Walek, Karel, M.; Tomas, H. Numerical analysis of RTD curves and inclusions removal in a multi-strand asymmetric tundish with different configuration of impact pad. Metals, 2020, 10, 1-20, https://www.mdpi.com/2075-4701/10/7/849. 